\title{
The effect of rapeseed oil-based polyols on the thermal and mechanical properties of ureaurethane elastomers
}

\author{
Kamila Mizera ${ }^{1}$ (D) . Joanna Ryszkowska ${ }^{1} \cdot$ Maria Kurańska² $^{2}$ \\ Aleksander Prociak ${ }^{2}$
}

Received: 20 November 2018 / Revised: 4 February 2019 / Accepted: 5 April 2019 /

Published online: 12 April 2019

(c) The Author(s) 2019

\begin{abstract}
Two types of rapeseed oil-based polyols in the content of $20 \mathrm{wt} \%$ and $50 \mathrm{wt} \%$ were used for synthesis of ureaurethane elastomers (EPUU) with isocyanate index 1.07. The bio-polyols were synthesized by epoxidation and opening of oxirane rings using isopropanol (RO) and diethylene glycol (MK). The aim of this work was to evaluate the impact of bio-polyols on the thermal and mechanical properties of the manufactured EPUUs, produced with poly(ethylene adipate) (PEA). Differences in the structure of used bio-polyols caused changes in the number of hydrogen bonds and degree of phase separation in EPUUs. As the content of bio-polyols increases, the number of hydrogen bonds connecting the rigid segments of these materials is reduced. The consequence of these changes is variation in the thermal characteristics of these materials. Cross-linking density calculated from dynamical mechanical thermal analysis increases for materials with $20 \%$ of both types of rapeseed oilbased polyols and is the highest for material 80PEA/20MK. An introduction of the MK polyol also resulted in an increase in the elongation at break of the modified elastomers.
\end{abstract}

Keywords Ureaurethane elastomers · Rapeseed oil · Degradation · Thermal properties $\cdot$ Mechanical properties

Kamila Mizera

kamila.mizera.dokt@pw.edu.pl

1 Faculty of Materials Science and Engineering, Warsaw University of Technology, Woloska 141, 02-507 Warsaw, Poland

2 Faculty of Chemical Engineering and Technology, Cracow University of Technology, Warszawska 24, 31-155 Cracow, Poland 


\section{Introduction}

In recent years, the introduction of plant components to polyurethane (PUR) systems meets all the ideas of sustainable development and is an important challenge for chemical companies [1]. PURs are well known and widely used because of their excellent properties and wide applications. The production of PURs is based on the two most important components: polyols and isocyanates. Nowadays, one of the problems of PUR industry is their dependence on petroleum feedstock [2]. The increasing interest of industry of polyols from vegetable oils is observed for a few years [3]. In the PUR production, the natural oil polyols can be used to replace petrochemical components [4]. Polyols can be synthesized from different natural materials, including lignin, cellulose and oils $[5,6]$. There are many publications about obtaining PURs from different vegetable oil-based polyols such as soybean oil [7-9], rapeseed oil [10], sunflower oil [11], linseed oil [12] or castor oil [13]. Most of the PUR materials modified with vegetable oil polyols are foams [14], coatings [15], films [16] and adhesives [17]. To obtain PURs using renewable raw materials, there are some aspects that have to be considered as hydroxyl value, functionality and chemical structure of dangling chains [16].

In the literature, only few researchers deal with results on the modification of PUR elastomers by using vegetable polyols. Auguścik et al. [18, 19] examined the effect of added rapeseed oil-based polyol from 0 to $50 \mathrm{wt} \%$ to PUR elastomers. These studies have shown that new material obtained using $50 \mathrm{wt} \%$ content of the rapeseed oil-based polyol was characterized by the best storage modulus and friction coefficient. And also, that use of rapeseed oil-based polyol resulted in only a slight reduction in their heat resistance as compared to the sample prepared without bio-polyol and slightly worsens their fire resistance.

However, no sufficient data on the production of ureaurethane elastomers with rapeseed oil-based polyols have been reported yet. The limited number of publications concerning the application properties and synthesis of EPUUs produced using rapeseed oil-based polyols results in the low commercial availability of these products. Therefore, the current modifications of commercial products are mainly limited to design changes resulting in a variety of shapes and colors of the products and the packaging, especially in the production of polyurethane foams [4], and adhesives and coatings [20]. In this regard, the introduction of new ecological products manufactured using rapeseed oil-based polyols would significantly improve their competitiveness on the market.

In our previous works, we used tall oil-based polyols as chain extender [21, $22]$ and soybean oil-based polyols [8,9]. The results from these study show that addition or total replacement fossil-based polyol, gives higher thermal resistance, rigidity and stronger fire resistance.

In this study, the results of thermal mechanical properties of ureaurethane elastomers (EPUU) synthesized using $20 \mathrm{wt} \%$ and $50 \mathrm{wt} \%$ of rapeseed oil-based polyols. The bio-polyols were synthesized using epoxidation reaction and opening of oxirane rings with isopropanol (RO) and diethylene glycol (MK). The different oxirane ring opening agents were applied in order to obtain bio-polyols 
with primary and secondary hydroxyl groups and to evaluate their influence on thermal stability as well as mechanical properties of the ureaurethane elastomers in comparison with the reference EPUU based only on petrochemical polyol.

\section{Experimental}

\section{Materials}

EPUUs were prepared by using a polyester poly(ethylene adipate) (PEA)—Polios $60 / 20$, with molar mass of $2318 \mathrm{~g} / \mathrm{mol}$, with hydroxyl value $52.4 \mathrm{mgKOH} / \mathrm{g}$, acid value $1 \mathrm{mgKOH} / \mathrm{g}$, content of water $0.1 \mathrm{wt} \%$, (Purinova, Bydgoszcz, Poland) and 4,4'-diphenylmethane diisocyanate (MDI) (Sigma-Aldrich Co., Poznan, Poland). As chain extender, the dicyandiamide (DYDI) - Omnicure 5, with molar mass of $84 \mathrm{~g}$ / mol (Emerald Performance Materials Company, USA) was used. In case of modified EPUUs, the petrochemical polyol was replaced with two rapeseed oil-based polyols (RO and MK) in an amount of $20 \mathrm{wt} \%$ and $50 \mathrm{wt} \%$. Both rapeseed oil-based polyols were prepared by Faculty of Chemical Engineering and Technology, at Cracow University of Technology.

\section{Synthesis of bio-polyols}

RO and MK with hydroxyl value 58 and $42.9 \mathrm{mgKOH} / \mathrm{g}$, acid value 1.83 and $4.0 \mathrm{mgKOH} / \mathrm{g}$, content of water 0.04 and $0.06 \mathrm{wt} \%$, number molecular weight 1255 and $2387 \mathrm{~g} / \mathrm{mol}$, respectively, were synthesized using isopropanol and diethylene glycol as oxirane ring openers (Fig. 1a, b, respectively). The synthesis method of this polyol is described in our earlier publications [4, 23-26].

\section{Synthesis of the ureaurethane elastomers}

EPUUs were synthesized by one step method, with the mole ratio of the substrates $(\mathrm{PEA}+\mathrm{RO}$ or $\mathrm{MK}) / \mathrm{MDI} / \mathrm{DYDI}$ was $2: 5: 3$. The content of hard segments (HS) in tested EPUUs was calculated with the equation:

$$
\mathrm{HS}=\frac{m M_{\mathrm{MDI}}+k M_{\mathrm{DYDI}}}{n M_{\mathrm{polyol}}+m M_{\mathrm{MDI}}+k M_{\mathrm{DYDI}}} \cdot 100 \%
$$

where $M_{\mathrm{MDI}}$-molar mass of MDI, g/mol; $M_{\mathrm{DYDI}}$-molar mass of DYDI, $\mathrm{g} / \mathrm{mol}$;

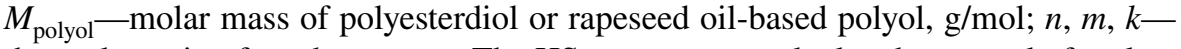
the molar ratio of used reactants. The HS content was calculated separately for elastomers with PEA, MK and RO polyols. The HS content was then calculated taking into account the appropriate percentage of the used polyols and summarized them. The characterization of the materials was presented in Table 1.

The PEA with DYDI was melted and degassed for $1.5 \mathrm{~h}$ at $150 \pm 5{ }^{\circ} \mathrm{C}$ and $6 \mathrm{hPa}$ with intense stirring. Then, the PEA was cooled to $80 \pm 3{ }^{\circ} \mathrm{C}$ before the 


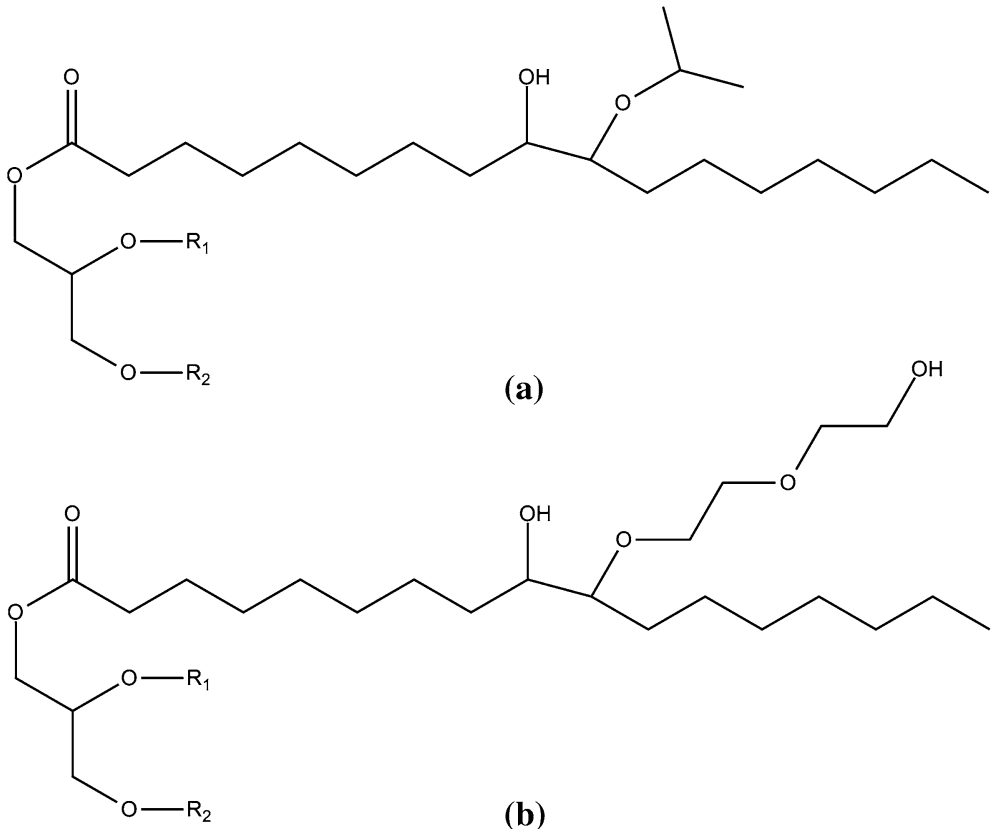

Fig. 1 Scheme of rapeseed oil-based polyols: RO (a) and MK (b). $R_{1}, R_{2}$-fatty acid chains

Table 1 Characteristics of tested materials

\begin{tabular}{lll}
\hline Samples & PEA/RO or MK (wt $\%)$ & HS (wt $)$ \\
\hline 100PEA & $100 / 0$ & 24.5 \\
80PEA/20MK & $80 / 20$ & 24.4 \\
50PEA/50MK & $50 / 50$ & 24.2 \\
80PEA/20RO & $80 / 20$ & 26.3 \\
50PEA/50RO & $50 / 50$ & 29.6 \\
\hline
\end{tabular}

$H S$ hard segments

RO or MK polyol was added. The mixture was then stirred for $30 \mathrm{~min}$. Next, the mixture was cooled to $60 \pm 3{ }^{\circ} \mathrm{C}$ and MDI was added and stirred for $10 \mathrm{~min}$. The prepared mixture was then poured into a duraluminium mold and annealed for $18 \mathrm{~h}$ at $110{ }^{\circ} \mathrm{C}$. The samples were tested after 30 days of seasoning under ambient conditions. As a comparative material, EPUU consisting of $100 \mathrm{wt} \%$ of PEA polyol was prepared. The process of its production is as described above, omitting the part related to the application of rapeseed oil-based polyol.

The scheme of the reaction of EPUUs with rapeseed oil-based polyols is shown in Fig. 2. 


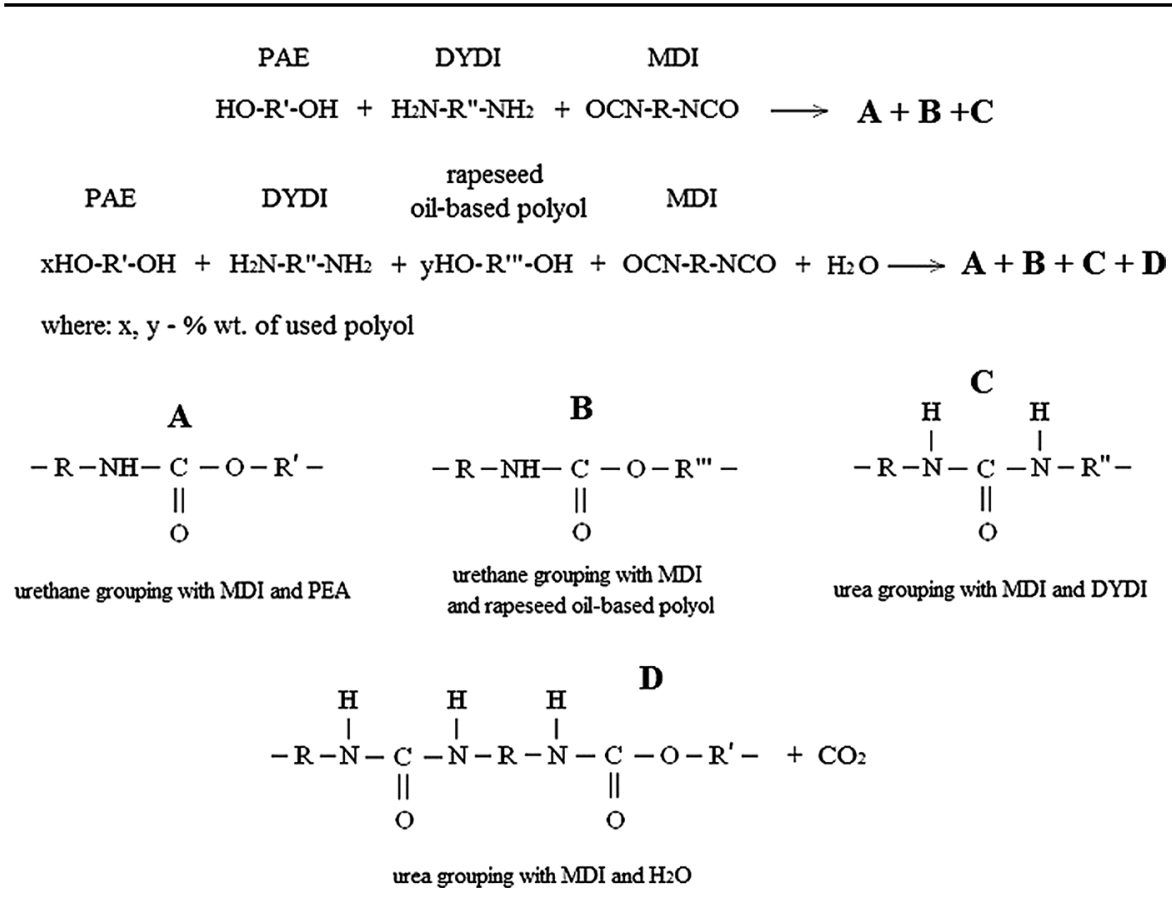

Fig. 2 The reaction of tested EPUUs with rapeseed oil-based polyols

\section{Characterization of used polyols and ureaurethane elastomers}

The RO and MK polyols, and EPUUs were tested by Fourier transform infrared spectroscopy (FTIR) using a Nicolet 7600 (Thermo Electron Corporation, USA). Spectra were recorded as a sum of 64 scans using a spectral range from 4000 to $400 \mathrm{~cm}^{-1}$, with a resolution of $4 \mathrm{~cm}^{-1}$. The data analysis was performed using Omnic software. A baseline correction for $\mathrm{CO}_{2}$ and $\mathrm{H}_{2} \mathrm{O}$ was performed to eliminate the impact of the compound residues from the analysis. The bands in the range of $1780-1640 \mathrm{~cm}^{-1}$ corresponding to the stretching vibrations of the $-\mathrm{C}=\mathrm{O}$ group were specifically examined. For the determination of the intensity of individual signals, a split of the multiplet peak of the carbonyl band was performed via Gauss curve fitting using the Omnic 7.3 program. The baseline for the broadband was drawn linearly from 1650 to $1780 \mathrm{~cm}^{-1}$. On the basis of the intensity of the bands, the $\mathrm{R}_{\mathrm{C}=\mathrm{O}}$ index was calculated. This index defined the participation of urethane and urea groupings forming hard segments, linked with the hydrogen bond of the $-\mathrm{C}=\mathrm{O}$ groups [27]:

$$
R_{\mathrm{C}=\mathrm{O}}=\frac{A_{\mathrm{B} 1}+A_{\mathrm{B} 2}}{A_{\mathrm{F} 1}+A_{\mathrm{F} 2}}
$$

where $A_{\mathrm{B} 1}$ and $A_{\mathrm{B} 2}$ are the respective surface areas of the bands from the vibrations bound by the hydrogen bond of the carbonyl groups of urea (B1) (1640-1680 $\mathrm{cm}^{-1}$ ) 
and urethane (B2) $\left(1705-1727 \mathrm{~cm}^{-1}\right) . A_{\mathrm{F} 1}$ and $A_{\mathrm{F} 2}$ are the respective surface areas of bands from vibrations unbounded with the hydrogen bond of the carbonyl groups of urea (F1) (1690-1701 $\left.\mathrm{cm}^{-1}\right)$ and urethane (F2) $\left(1736-1780 \mathrm{~cm}^{-1}\right)$ bonding.

Based on the $R_{\mathrm{C}=\mathrm{O}}$ index, the degree of phase separation (DPS) was calculated. This value defines the participation of hard segments bound with the hydrogen bond [28]:

$$
\mathrm{DPS}=\frac{R_{\mathrm{C}=\mathrm{O}}}{1+R_{\mathrm{C}=\mathrm{O}}}
$$

The thermal stability of the rapeseed oil-based polyols and materials was defined by thermogravimetric analysis using a Q500 analyzer (TA Instruments, USA). The tested $10 \mathrm{mg}$ samples were heated from room temperature to $800{ }^{\circ} \mathrm{C}$ for EPUUs with a heating rate of $10{ }^{\circ} \mathrm{C} / \mathrm{min}$. Tests were carried out in a nitrogen atmosphere with a flow rate of $90 \mathrm{ml} / \mathrm{min}$. EPUUs were also tested in air atmosphere in the same temperature range.

Evolved gases from the TGA of EPUUs were transported through the TGA/ FTIR transfer line using air atmosphere. Samples of about $15 \mathrm{mg}$ were heated from room temperature to $800{ }^{\circ} \mathrm{C}$ at a rate of $20{ }^{\circ} \mathrm{C} / \mathrm{min}$. The FTIR gas cell was held at $240{ }^{\circ} \mathrm{C}$, and the temperature of the transfer line was set to $250{ }^{\circ} \mathrm{C}$, to reduce the possibility of evolved products condensing along the transfer line.

The DSC analysis of polyols and EPUUs was performed using a differential scanning calorimeter Q1000 (TA Instruments, USA). Samples (5 mg) were closed in hermetic aluminum cups and heated at $10{ }^{\circ} \mathrm{C} / \mathrm{min}$ in the temperature range -90 to $250^{\circ} \mathrm{C}$.

EPUUs also were tested mechanical and physico-mechanical properties. The dynamic mechanical thermal analysis (DMTA) was carried out on a TA Instruments DMA Q800 (USA). This study was conducted using cast rectangularshaped samples with dimensions $60 \times 10 \times 2 \mathrm{~mm}$ and a two-point bending method. Samples were heated at $3{ }^{\circ} \mathrm{C} / \mathrm{min}$ in a temperature range between -100 and $110{ }^{\circ} \mathrm{C}$, using a constant frequency of $1 \mathrm{~Hz}$ and an amplitude of $25 \mu \mathrm{m}$. The test was carried out in a nitrogen atmosphere. Based on the results of the analysis of thermal mechanical properties (DMA), cross-linking density ( $\nu \mathrm{c})$ was determined. $\nu \mathrm{c}$ of the ureaurethane understood as the inverse of the average molecular weight between network nodes, was calculated using an expression based on Flory's rubber elasticity theory [29]:

$$
v c=\frac{E_{\mathrm{T}}}{3 R T}
$$

where $\nu \mathrm{c}(\mathrm{mol} / \mathrm{kg})$-cross-link density, $\rho$-density, $E_{\mathrm{T}}(\mathrm{Pa})$ is storage modulus measured at the rubbery plateau, $R=8.31 \mathrm{~J} \mathrm{~K}^{-1} \mathrm{~mol}^{-1}$ is universal gas constant, and $T(\mathrm{~K})$ is absolute temperature at which the plateau of $E_{\mathrm{T}}$ was determined.

The static tensile test was performed on a tensile machine (Instron 1115) according to PN-EN ISO 527. The cast paddle-shaped samples with dimensions $2.5 \times 2 \mathrm{~mm}$ and measuring length $20 \mathrm{~mm}$, were stretched at a speed of $500 \mathrm{~mm} /$ $\min$. 


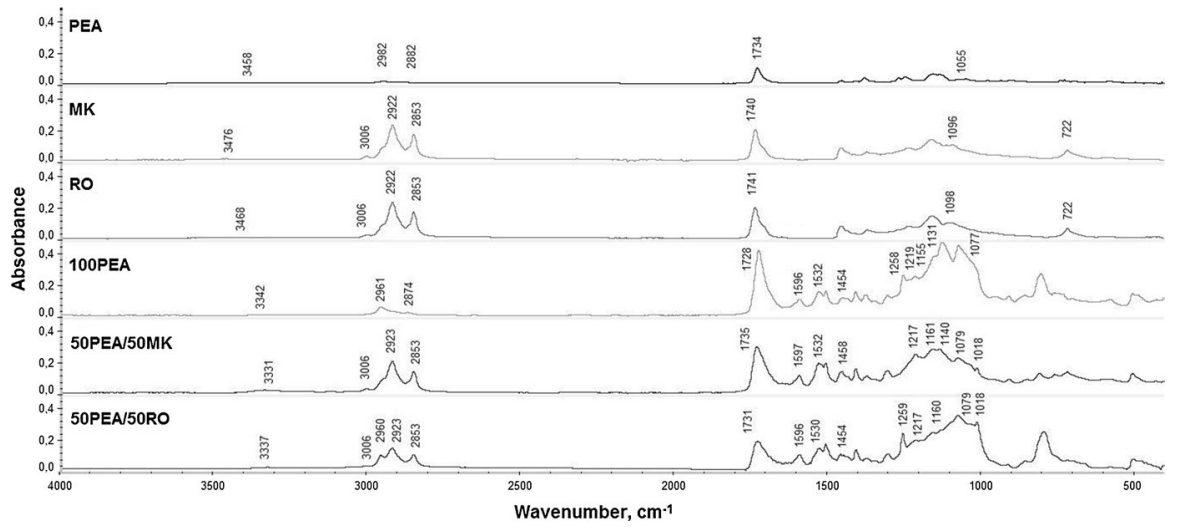

Fig. 3 FTIR spectra of polyols, 100PEA and EPUUs with 50\% of MK and RO

Table 2 Interpretation of the FTIR spectra of the used polyols

\begin{tabular}{llllr}
\hline $\begin{array}{l}\text { Wavenumber for } \\
\text { bands }\left(\mathrm{cm}^{-1}\right)\end{array}$ & Band description & PEA & MK & RO \\
\hline $3400-3500$ & O-H (stretching) & 3458 & 3476 & 3468 \\
3006 & C-H (asymmetric stretching) & - & 3006 & 3006 \\
$2982-2922$ & C-H (asymmetric stretching) & 2982 & 2922 & 2922 \\
$2982-2852$ & C-H (symmetric stretching) & 2882 & 2853 & 2853 \\
1727 & C=O (stretching) & 1734 & 1740 & 1741 \\
1050 & C-O (stretching) & 1055 & 1096 & 1098 \\
722 & Correspond to the $\left(\mathrm{CH}_{2}\right)_{n}-$ sequence of the & - & 722 & 722 \\
& aliphatic chains of the fatty acids & & & \\
\hline
\end{tabular}

\section{Results and discussion}

\section{The chemical constitution analysis of polyols and EPUUs}

Change in chemical structure of used rapeseed polyols and EPUUs was tested by infrared spectroscopy (FTIR). The FTIR spectra of used polyols and EPUUs with $50 \%$ of rapeseed oil-based polyols are shown in Fig. 3.

The wavenumber of the peaks occurring on the FTIR spectra of used polyols was interpreted and summarized in Table 2. The peak correlated with -OH groups for bio-based polyols is shifted toward the lower wavenumbers than in case of PEA. For RO and MK polyols, the peak correlated with $\mathrm{C}-\mathrm{H}$ stretching vibrations of double bond $\mathrm{CH}=\mathrm{CH}$ is observed $\left(3006 \mathrm{~cm}^{-1}\right)$ [30]. Distinct changes were observed in the range of symmetric and asymmetric $\mathrm{C}-\mathrm{H}$ bonds which are shifted toward to the lower wavenumbers than PEA (Table 2). Similar effect is observed in the region of the $\mathrm{C}=\mathrm{O}$ stretching bond. For $\mathrm{RO}$ and $\mathrm{MK}$ polyols, the shift toward the higher wavenumbers and the decrease in intense of 
absorbance of the bands were noticed (Fig. 3). The peak correlated with $\mathrm{C}-\mathrm{O}$ stretching bond is shifted toward to the higher wavenumbers than PEA, whereas for RO and MK polyols, the peak at $722 \mathrm{~cm}^{-1}$ correlated with the presence of fatty acids is observed.

The FTIR spectra confirmed the presence of chemical groups for the ureaurethane elastomers (Fig. 3). Signals in the range of $3341-3300 \mathrm{~cm}^{-1}$ were the result of symmetric and asymmetric stretching vibrations of the $\mathrm{N}-\mathrm{H}$ groups present in urethane group [31], which are involved in formation of hydrogen bonds [32]. For EPUUs with bio-based polyols, the peak at $3006 \mathrm{~cm}^{-1}$ is observed, which is the result of added polyols. The signals in the range $2961-2923 \mathrm{~cm}^{-1}$ and $2953-2874 \mathrm{~cm}^{-1}$ are correlated with symmetric and asymmetric $\mathrm{CH}_{2}$ stretching vibrations, respectively. For EPUUs with RO, the peak at $2960 \mathrm{~cm}^{-1}$ is observed. This is the effect of the different weight ratio of the polyols used (PEA/RO) [18]. The signal at $1728-1740 \mathrm{~cm}^{-1}$ indicates the presence of $\mathrm{C}=\mathrm{O}$ carbonyl bonds in urethane groups, in hard segments [33]. Peak at $1596 \mathrm{~cm}^{-1}$ is associated with the presence of aromatic groups. Signals in the range of $1530-1532 \mathrm{~cm}^{-1}$ are associated with urethane $\mathrm{N}-\mathrm{H}$ bending vibrations and $\mathrm{C}-\mathrm{N}$ stretching vibrations [34]. The signals at $1453-1465 \mathrm{~cm}^{-1}$ are connected with scissoring vibrations of $-\mathrm{CH}_{2}$ groups. Peak at $1217 \mathrm{~cm}^{-1}$ is the result of $\mathrm{C}-\mathrm{N}$ stretching vibrations. The multiplet band in the range $1050-1260 \mathrm{~cm}^{-1}$ is assigned to $\mathrm{C}-\mathrm{O}$ bonds in flexible segments [33].

Changes in absorbance and displacement of the signals observed in the FTIR spectra (Fig. 3) are the result of EPUU system modification with bio-polyols.

For both types of EPUUs with RO polyols, the increase in absorbance of the bands originating from the stretching vibrations bonds $\mathrm{C}-\mathrm{O}\left(2922 \mathrm{~cm}^{-1}\right.$, $2853-2874 \mathrm{~cm}^{-1}$ ) is observed. The absorbance of the bands originating from the vibrations of carbonyl bond $\mathrm{C}=\mathrm{O}\left(1728-1740 \mathrm{~cm}^{-1}\right)$ decreased with added $\mathrm{RO}$ and MK. These changes also affect the absorbance bands from multiplet carbonyl bonds. In order to evaluate these changes, the deconvolution of the multiplet carbonyl signals was performed.

The data included in Table 3 show that for EPUUs with MK and RO, the degree of phase separation (DPS) decreases for these materials compared to reference sample. Increased content of MK polyol in soft phase in tested EPUUs causes an increase in the formation of hydrogen bonds in hard phase $(R=1.52$ for $80 \mathrm{PEA} / 20 \mathrm{MK}, R=1.10$ for 50PEA/50MK) than in EPUUs with RO polyol $(R=1.30$ for $80 \mathrm{PEA} / 20 \mathrm{RO}, R=1.05$ for 50PEA/50RO). The increase in the

Table 3 Hydrogen bond index (R) and degree of phase separation (DPS) for the tested EPUUs

\begin{tabular}{lll}
\hline Samples & $R$ & DPS $(\%)$ \\
\hline 100PEA & 1.49 & 59.9 \\
80PEA/20MK & 1.52 & 60.3 \\
50PEA/50MK & 1.10 & 52.4 \\
80PEA/20RO & 1.30 & 56.5 \\
50PEA/50RO & 1.05 & 51.3 \\
\hline
\end{tabular}


formation of hydrogen bonds and degree of phase separation, testifies the increase in the degree of physical cross-linking [25] in these materials. Scheme of hydrogen bonds connecting $-\mathrm{C}=\mathrm{O}$ and $-\mathrm{N}-\mathrm{H}$ bonds originating from the polyols and isocyanate used to produce EPUUs is shown in Fig. 4.

\section{Thermal analysis}

The thermal decomposition of polyurethanes depends on the number of urethane linkages and on the aromatic moieties contents [36]. The thermal analysis of developed materials by TGA in nitrogen was conducted. The loss of weight (TG) and first derivative of the loss of weight (DTG) curves of tested materials are shown in Fig. 5. Decomposition of EPUUs usually starts with the dissociation of the urethane linkage, which decompose in lower temperature than urea linkage [25]. Low thermal stability of urethane linkages is explained by low dissociation energies of chemical bonds present in urethane linkage structure [36]. Next, the degradation of ester bonds in the soft segments and aromatic compounds is observed [21,37].

The temperature of $5 \%$ of weight loss $\left(T_{5 \%}\right)$ and residue at $600{ }^{\circ} \mathrm{C}\left(U_{600}\right)$ were determined from TG curve (Table 4). The two steps of degradation correlated with the temperature of maximum rate of degradation of hard $\left(T_{1}\right)$ and soft $\left(T_{2}\right)$ segments, the amounts of weight loss $\left(m_{1}, m_{2}\right)$ and the maximum rate of degradation $\left(V_{1}, V_{2}\right)$.

The temperature of initial thermal decomposition $\left(T_{5 \%}\right)$ is lower for both rapeseed oil-based polyols compared to petrochemical polyol. For PEA only, one stage of degradation at $382{ }^{\circ} \mathrm{C}\left(T_{2}\right)$ and the loss of $93.3 \%\left(m_{2}\right)$ with $1.87 \% /{ }^{\circ} \mathrm{C}\left(V_{2}\right)$ are observed (Table 4). Rapeseed oil-based polyols have two stages of degradation (Fig. 5a). First one, occurred at temperature $249{ }^{\circ} \mathrm{C}$ and $235^{\circ} \mathrm{C}\left(T_{1}\right)$ with weight loss of about $10.9 \%$ and $11.0 \%\left(m_{1}\right)$, with maximum rate of degradation $0.13 \% /{ }^{\circ} \mathrm{C}$ and

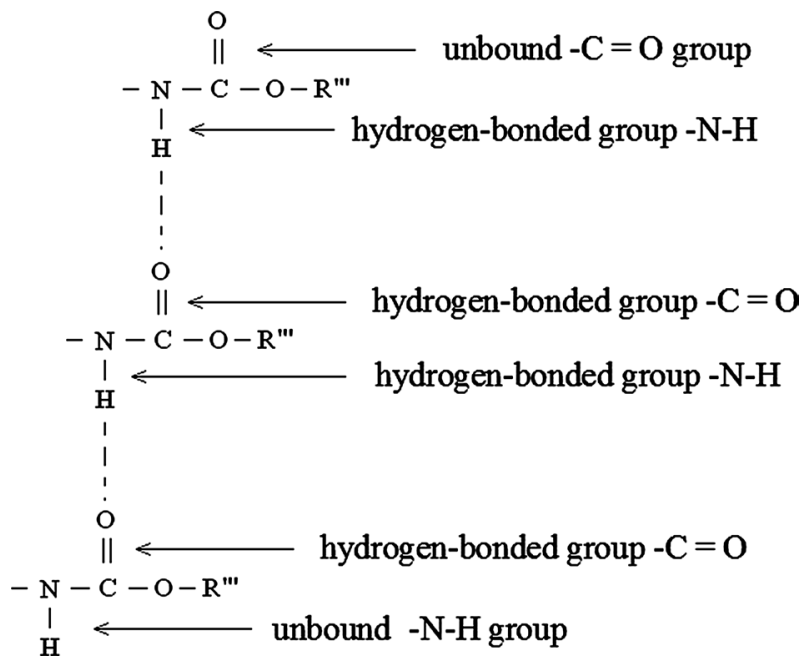

Fig. 4 Scheme of hydrogen bonding of groups $-\mathrm{C}=\mathrm{O}$ and $-\mathrm{N}-\mathrm{H}$ of urethane groupings [35], where $R^{\prime \prime \prime}$ is the residual of rapeseed oil-based polyol 


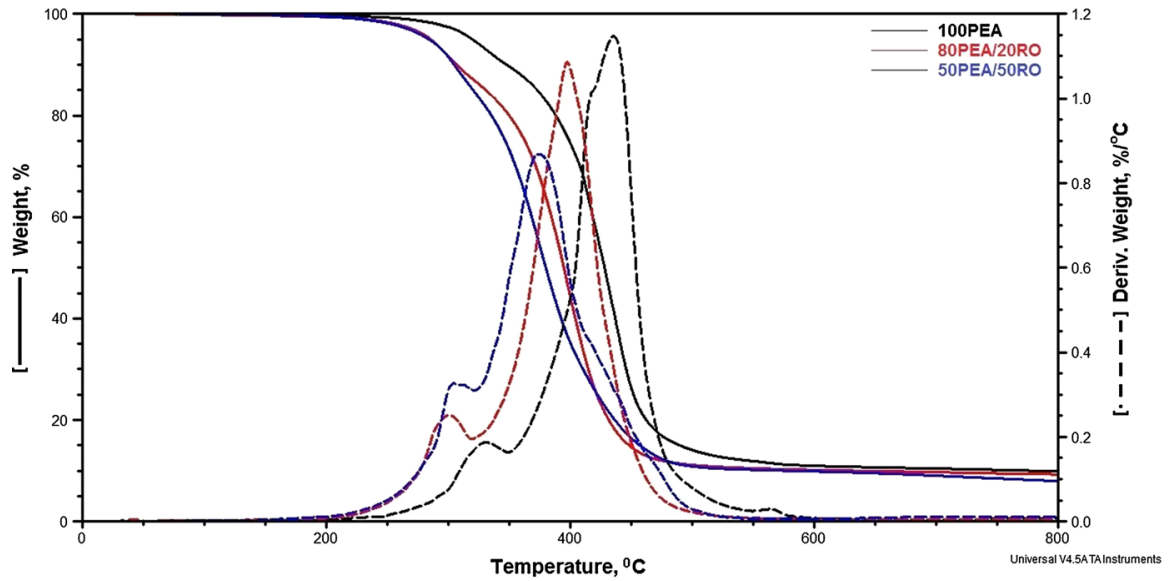

(a)

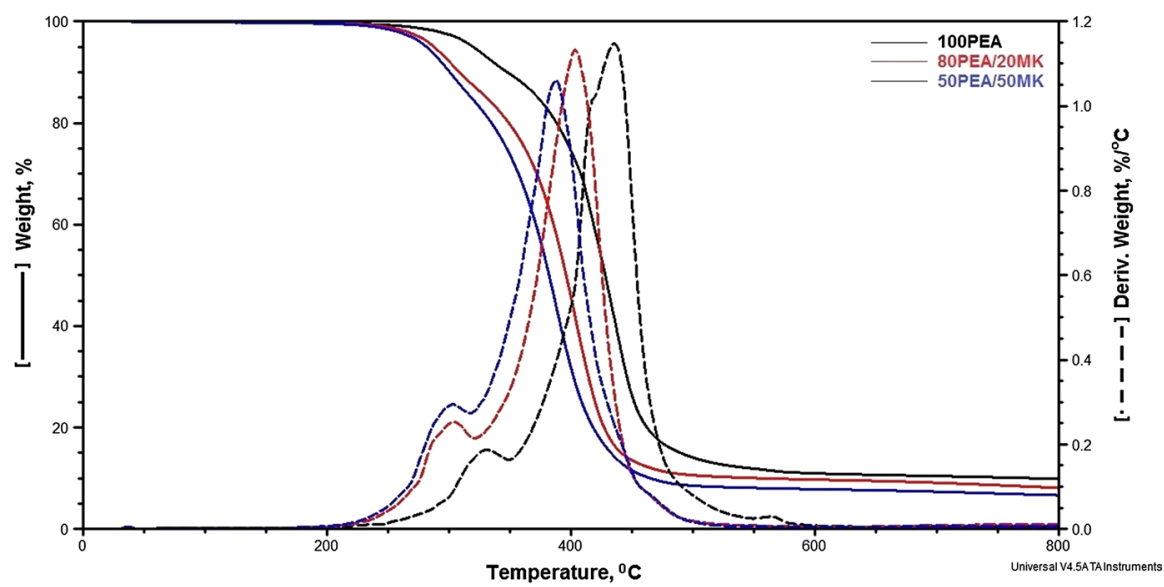

(b)

Fig. 5 Thermograms of TG and DTG of EPUUs with $\mathbf{a}$ MK and $\mathbf{b}$ RO polyols in nitrogen atmosphere

$0.14 \% /{ }^{\circ} \mathrm{C}\left(V_{1}\right)$, for $\mathrm{MK}$ and $\mathrm{RO}$ polyols, respectively. Probably, this is the effect of more branched structure of MK polyol with higher molecular weight. Second stage of degradation is observed at temperature $420{ }^{\circ} \mathrm{C}$ and $424{ }^{\circ} \mathrm{C}\left(T_{2}\right)$, with weight loss of about $86.5 \%$ and $87.4 \%\left(m_{2}\right)$ and with maximum rate of degradation $1.27 \% /{ }^{\circ} \mathrm{C}$ and $1.02 \% /{ }^{\circ} \mathrm{C}\left(V_{2}\right)$, for $\mathrm{MK}$ and $\mathrm{RO}$, respectively (Table 4).

The initial degradation temperature $T_{5 \%}$ of tested EPUUs, decreased with an increase in rapeseed oil-based polyols (Table 4). All EPUUs have two stages of degradation (Fig. 5b). The temperature of first step of degradation is higher for EPUUs with RO and MK polyols. The increase in weight loss from $9.5 \%$ to $11.7 \%\left(m_{1}\right)$ is also observed. This increase is higher for EPUUs with MK polyol (Table 4). For this step, no significant changes in maximum rate of degradation $\left(V_{1}\right)$ are observed. The second step of degradation occurred at $375-404{ }^{\circ} \mathrm{C}\left(T_{2}\right)$, 


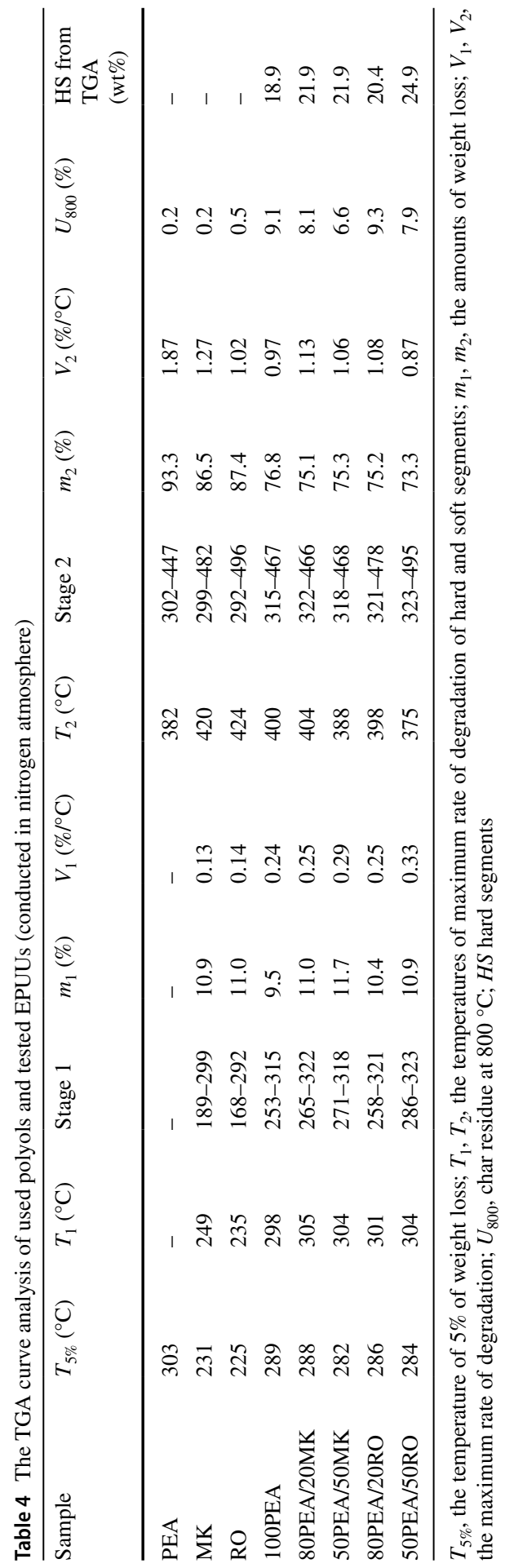


with weight loss at $73.3-76.8 \%\left(m_{2}\right)$ and with maximum rate of degradation from $0.87 \% /{ }^{\circ} \mathrm{C}$ to $1.13 \% /{ }^{\circ} \mathrm{C}\left(V_{2}\right)$. The addition of rapeseed oil-based polyols causes decrease in temperature $T_{2}$. The exception is the material 80PEA/20MK, where this temperature is higher ca. $4{ }^{\circ} \mathrm{C}$ than for 100PEA.

After degradation at $800{ }^{\circ} \mathrm{C}$, the amount of materials mass occurs at 6.6-9.3\% $\left(U_{800}\right)$. The residue at $800{ }^{\circ} \mathrm{C}$ decreased with an increase in rapeseed oil-based polyols content (Table 4).

DTG thermograms show that the multistage decomposition process in nitrogen is a complex weight loss process, which is why the DTG thermograms were split into constituent peaks [21].

In Fig. 6, the original DTG curve for the 50PEA/50MK was deconvoluted into separated curves using a Gaussian profile. The calculated curve, which was the sum of separated curves, agreed well with the original DTG trace.

The areas of deconvoluted peaks from DTG curves can be correlated with weight loss values at different stages of degradation. Table 4 shows the content of urethane and urea bonds in the hard segments, interpreted from DTG curves. In the range of $240-320{ }^{\circ} \mathrm{C}$, the dissociation of urethane bonds in the hard segments of EPUUs is observed [21]. At higher temperatures from 320 to $340{ }^{\circ} \mathrm{C}$, the degradation of urea bonds in hard segments is observed [38].

In this study, the presented elastomers theoretically contain 24.2-29.6 wt\% of HS. From the DTG curves, the hard segments content, described by the peaks connected with the degradation of the hard phase, occurs 18.9-24.9 wt\% (Table 4). These differences result from the fact that also the aromatic compounds are formed during degradation of hard segment. The content of this aromatic compound cannot be evaluated by this method.

Thermal stability of tested elastomers has also been analyzed in air atmosphere. The shapes of the thermograms in air are different that curves achieved in nitrogen atmosphere. The different is shown for the 50PEA/50MK in Fig. 7.

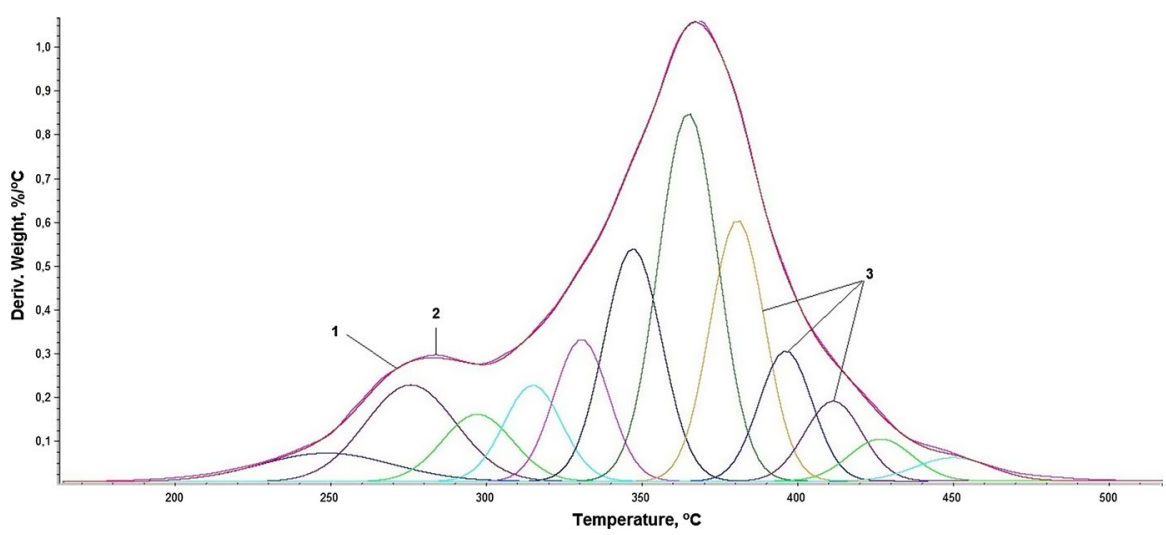

Fig. 6 Deconvoluted DTG curves of 50PEA/50MK: multiplet band (1), peaks after curve-fitting process (2), and component bands (3) 


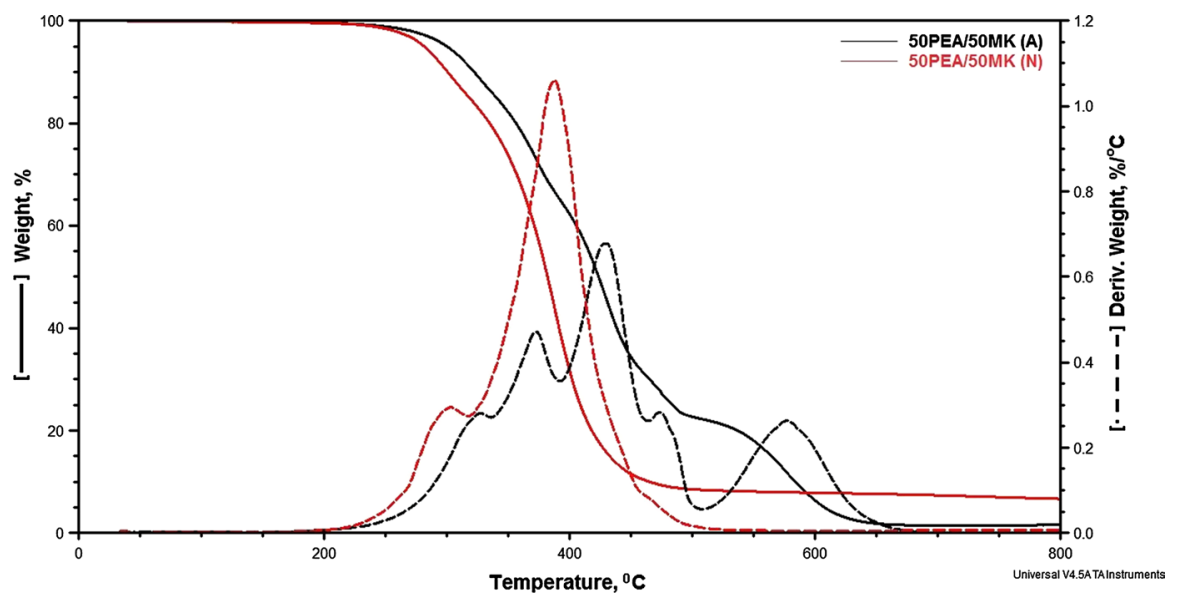

Fig. 7 Thermograms of 50PEA/50MK sample in air (A) and in nitrogen (N)

Different degradation steps were noticed for EPUUs in air atmosphere. The details of the TGA data for EPUUs in air atmosphere are shown in Table 5. For $50 \mathrm{PEA} / 50 \mathrm{MK}$ in nitrogen atmosphere, the degradation process is completed at $466{ }^{\circ} \mathrm{C}$, while in air atmosphere the end of degradation takes place at $650{ }^{\circ} \mathrm{C}$ (Fig. 7).

The temperature $T_{5 \%}$ for EPUUs tested in air atmosphere is higher than in the case of nitrogen atmosphere. This temperature decreases for EPUUs with rapeseed oil-based polyol, just like in nitrogen atmosphere.

Degradation in air atmosphere has more steps than in nitrogen atmosphere (Table 5). The first stage of degradation process occurred at $322-328{ }^{\circ} \mathrm{C}\left(T_{1}\right)$ and started at higher temperatures than in nitrogen atmosphere. During this stage, a degradation of hard segments occurs. The weight loss in this stage was $8.7-12.9 \%\left(m_{1}\right)$ and increased with an increase in rapeseed oil-based polyols content. The second stage of degradation occurs at $372-396{ }^{\circ} \mathrm{C}\left(T_{2}\right)$ and starts at lower temperatures than in nitrogen atmosphere. Higher content of rapeseed oil-based polyols in EPUUs causes a decrease in the temperature of sample degradation at this stage. The weight loss in this stage was $19.8-27.9 \%\left(m_{2}\right)$ and decreased with an increase in MK polyol, and increased with an increase in RO polyol. At this stage, the degradation of the rest of PUR hard segments is continued, but also the degradation of soft phases is already started. The third degradation stage takes place at temperature range $419-439{ }^{\circ} \mathrm{C}\left(T_{3}\right)$ with the highest weight loss of $34.6-45.3 \%\left(m_{3}\right)$. The exception is 50PEA/50RO sample for which the weight loss is $17.3 \%$. The fourth stage of degradation is observed only for materials with $50 \%$ of rapeseed oil-based polyols. This stage occurs at $474{ }^{\circ} \mathrm{C}$ and $469{ }^{\circ} \mathrm{C}\left(T_{4}\right)$ for 50PEA/50MK and 50PEA/50RO, respectively. Probably for this, materials degradation of the soft segments coming from rapeseed oil-based polyols has higher thermal resistance and reduce at higher temperatures. The fifth stage of degradation occurred at 578-607 ${ }^{\circ} \mathrm{C}\left(T_{5}\right)$ with weight loss at $20.4-24.2 \%\left(m_{5}\right)$. Addition of $20 \%$ of RO and MK polyols causes an increase 


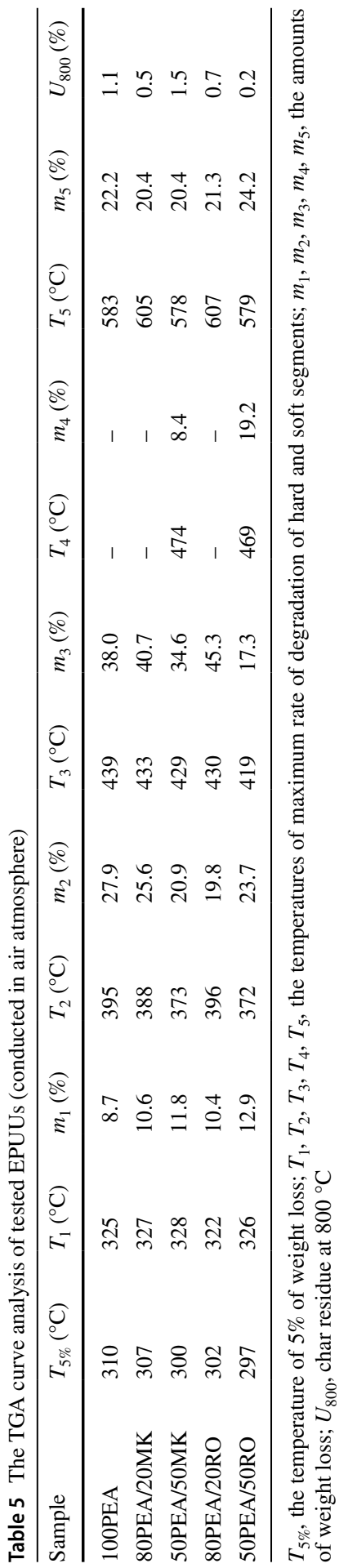


in this temperature. Such degradation can be explained by an oxidative reaction of double bonds in the long fatty acid chains of the rapeseed oil [38].

After degradation was carried out under nitrogen atmosphere at $800{ }^{\circ} \mathrm{C}$, still a significant amount of materials mass (6.6-9.3\%) remains. In contrast, in the degradation conducted under air atmosphere the amount of materials mass occurs at $0.2-1.5 \%$ [19].

The combination of TGA and FTIR techniques, can give direct information about volatile products of thermal degradation. The 3D TGA/FTIR spectra of the volatile products formed during thermal degradation of the materials: 100PEA, 50PEA/50MK and 50PEA/50RO, are shown in Fig. 8a-c, respectively. The FTIR spectra of the pyrolysis products at the maximum decomposition rate of these materials are shown in Fig. 8d-f, respectively.

Results for the material 100PEA show four steps of its thermal decomposition, while for materials 50PEA/50MK and 50PEA/50RO thermal degradation took place in five steps (Fig. 8). In the range of $4000-3500 \mathrm{~cm}^{-1}$, small signals were noticed, which could be related to $\mathrm{O}-\mathrm{H}$ stretching vibrations from water or hydroxyl-terminated compounds and $\mathrm{N}-\mathrm{H}$ stretching vibrations (from urea and amine group) [25]. In the case of 100PEA, spectra signals at $2963 \mathrm{~cm}^{-1}$ and $2887 \mathrm{~cm}^{-1}$, relating to $\mathrm{C}-\mathrm{H}$ stretching vibrations, are confirmed, while for the materials 50PEA/50MK and 50PEA/50RO they are much more intense and shifted: $2935 \mathrm{~cm}^{-1}$ and $2869 \mathrm{~cm}^{-1}$, and $2934 \mathrm{~cm}^{-1}$ and $2868 \mathrm{~cm}^{-1}$, respectively. In all spectra, the bands at $2359 \mathrm{~cm}^{-1}$ and $2322 \mathrm{~cm}^{-1}$, attributed to carbon dioxide, are observed [38]. The presence of $\mathrm{CO}_{2}$ is the effect of the decomposition of urethane groups [39]. Another group of signals is located between $1768 \mathrm{~cm}^{-1}$ and $1757 \mathrm{~cm}^{-1}$, and $1137-1143 \mathrm{~cm}^{-1}$; these signals correspond to $-\mathrm{C}-\mathrm{O}-\mathrm{C}$ and $\mathrm{C}-\mathrm{O}$ stretch vibration [40].

DSC analysis was performed to determine the temperatures corresponding to the physical phase transitions in tested EPUUs. The characteristic temperatures connected with glass transition $\left(T_{\mathrm{g}}\right)$ in soft phase and with changes in hard phase $\left(T_{01}\right.$ and $\left.T_{02}\right)$, and the enthalpy of these changes $\left(\Delta H_{01}\right.$ and $\left.\Delta H_{02}\right)$ were determined from first heating cycle. From the DSC curves, the thermal effects $\left(C_{\mathrm{p}}\right)$ associated with the glass transition in the soft phase, were also determined. All data are summarized in Table 6. The DSC thermograms are shown in Fig. 9.

To understand the changes in physical phase transitions of tested EPUUs, the DSC analysis of used polyols was also performed (Table 6). The glass transition temperature $\left(T_{\mathrm{g}}\right)$ is the lowest for polyester PEA at temperature $-49.4{ }^{\circ} \mathrm{C}$. In case of rapeseed-based polyols, an increase of $T_{\mathrm{g}}$ to $-45.9{ }^{\circ} \mathrm{C}$ is observed. The thermal effects $\left(C_{\mathrm{p}}\right)$ associated with the glass transition in the soft phase, which decrease in the range from 0.821 (PEA) to $0.645 \mathrm{~J} / \mathrm{g}{ }^{\circ} \mathrm{C}$ (RO), are visible for the tested polyols.

The DSC thermogram of PEA shows one endothermic peak with a minimum at the temperature of $50.9^{\circ} \mathrm{C}$ and with enthalpy $86.7 \mathrm{~J} / \mathrm{g}$. For MK and RO polyols, two endothermic peaks at a minimum at the temperatures $-9.6{ }^{\circ} \mathrm{C}$ and $-6.0{ }^{\circ} \mathrm{C}\left(T_{01}\right)$, and $94.2{ }^{\circ} \mathrm{C}$ and $89.9{ }^{\circ} \mathrm{C}\left(T_{02}\right)$ are observed (Table 6). The enthalpy of this changes are $5.04 \mathrm{~J} / \mathrm{g}$ and $2.84 \mathrm{~J} / \mathrm{g}\left(\Delta H_{01}\right)$, and $38.89 \mathrm{~J} / \mathrm{g}$ and $16.43 \mathrm{~J} / \mathrm{g}\left(\Delta H_{02}\right)$, respectively. Also, for rapeseed-based polyols exothermic transition at $182.4{ }^{\circ} \mathrm{C}$ and $157.6{ }^{\circ} \mathrm{C}\left(T_{\mathrm{r}}\right)$ was observed, respectively (Table 6). This temperature is associated with temperature of decomposition of unsaturated fatty acids in polyols [18]. 


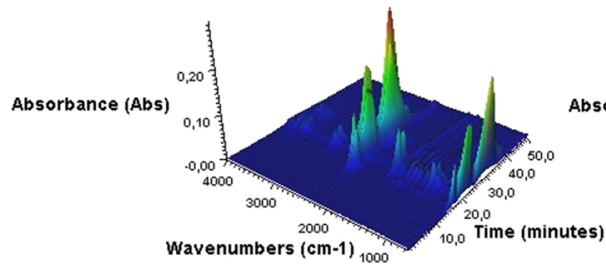

(a)

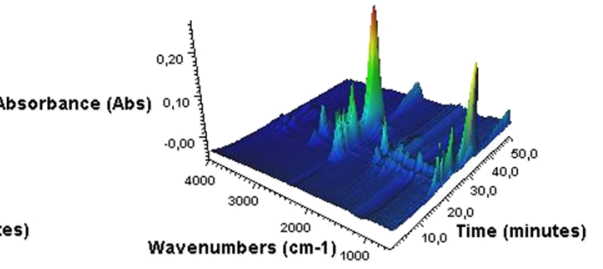

(b)

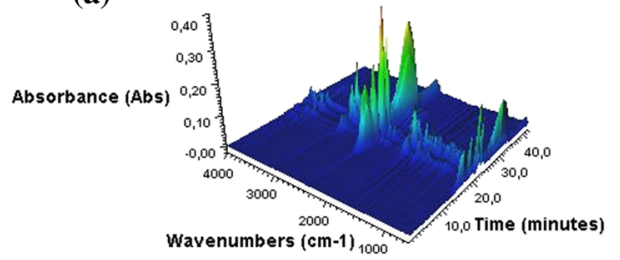

(c)

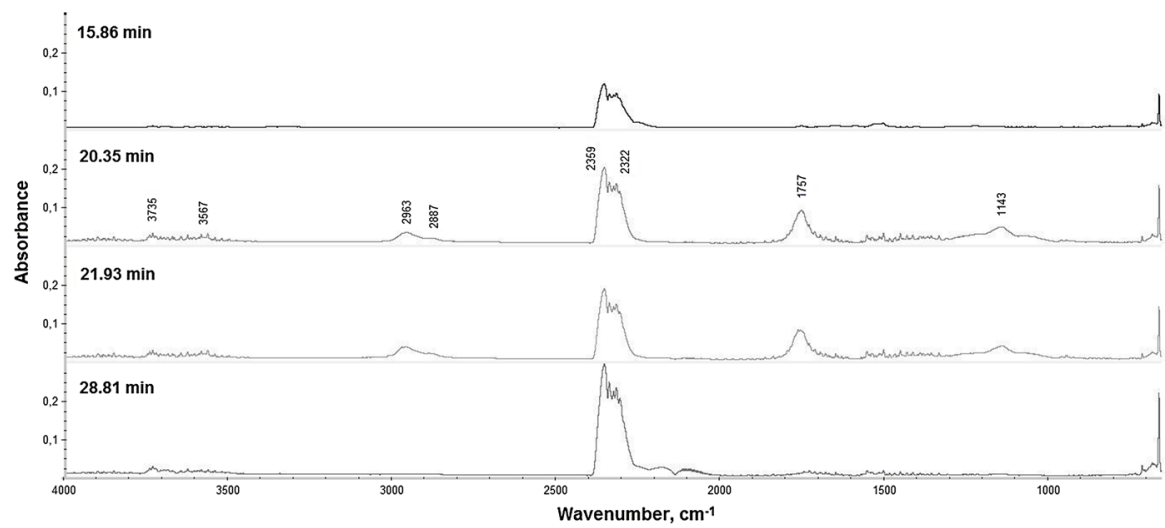

(d)

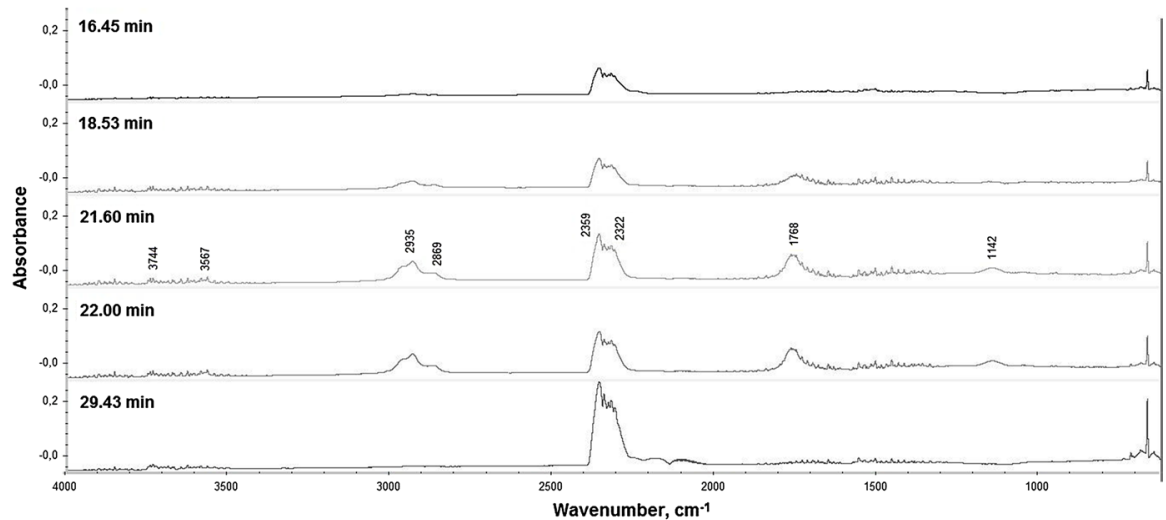

(e)

Fig. 8 The 3D TGA/FTIR spectra of 100PEA (a), 50PEA/50MK (b) and 50PEA/50RO (c) together with the FTIR spectra of volatilized pyrolysis products emitted at the maximum evolution rate from 100PEA (d), 50PEA/50RO (e) and 50PEA/50RO (f) 


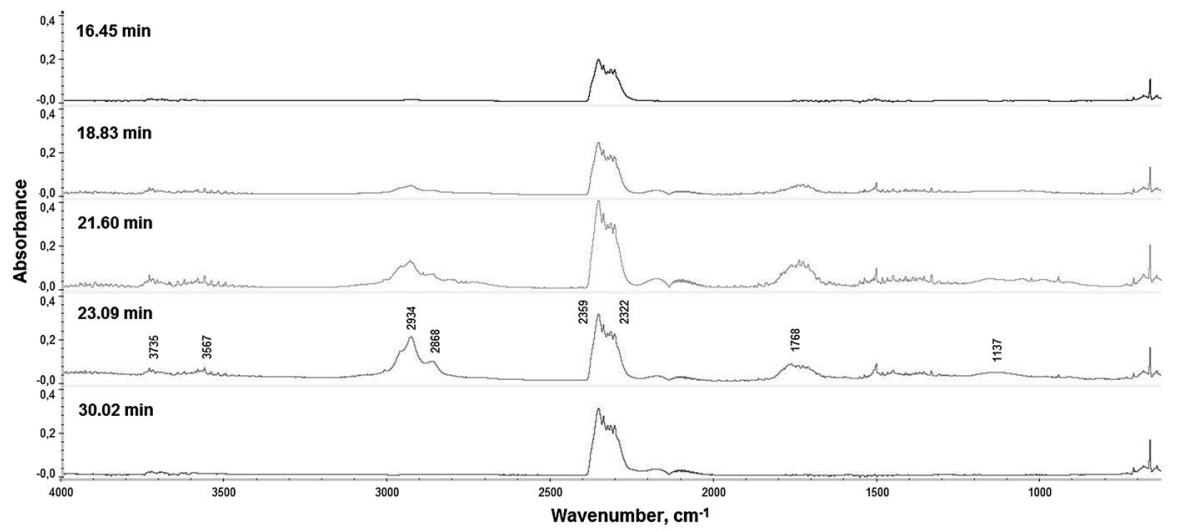

(f)

Fig. 8 (continued)

Table 6 The DSC analysis of used polyols and tested EPUUs

\begin{tabular}{llllllll}
\hline Sample & $T_{\mathrm{g}}\left({ }^{\circ} \mathrm{C}\right)$ & $C_{\mathrm{p}}\left(\mathrm{J} / \mathrm{g}{ }^{\circ} \mathrm{C}\right)$ & $T_{01}\left({ }^{\circ} \mathrm{C}\right)$ & $\Delta H_{01}(\mathrm{~J} / \mathrm{g})$ & $T_{02}\left({ }^{\circ} \mathrm{C}\right)$ & $\Delta H_{02}(\mathrm{~J} / \mathrm{g})$ & $T_{\mathrm{r}}\left({ }^{\circ} \mathrm{C}\right)$ \\
\hline PEA & -49.4 & 0.821 & 50.9 & 86.7 & - & - & - \\
MK & -49.0 & 0.818 & -9.6 & 5.04 & 94.2 & 38.89 & 182.4 \\
RO & -45.9 & 0.645 & -6.0 & 2.84 & 89.9 & 16.43 & 157.6 \\
100PEA & -32.8 & 0.378 & - & - & 117.3 & 4.13 & - \\
80PEA/20MK & -31.5 & 0.351 & - & - & 119.9 & 1.80 & 180.8 \\
50PEA/50MK & -30.3 & 0.280 & - & - & - & - & 171.5 \\
80PEA/20RO & -32.2 & 0.329 & - & - & 92.5 & 4.51 & 185.2 \\
50PEA/50RO & -29.2 & 0.251 & - & - & 96.4 & 5.77 & 176.0 \\
\hline
\end{tabular}

$T_{\mathrm{g}}$, glass transition temperature; $C_{\mathrm{p}}$, the thermal effects associated with the glass transition; $T_{01}, T_{02}$, the temperatures connected with changes in hard phase; $\Delta H_{01}, \Delta H_{02}$, the enthalpy of changes in hard phase; $T_{\mathrm{r}}$, the temperature associated with exothermic transition of rapeseed oil-based polyols

The glass transition temperature $\left(T_{\mathrm{g}}\right)$ of the soft phase is in the range from -32.8 to $-29.2{ }^{\circ} \mathrm{C}$ and increases for EPUUs with rapeseed-based polyols (Table 6). The shift of Tg to higher temperatures can be related with the presence of molecules with different chain length which influences on mobility of polymer chain [41]. The thermal effect $\left(C_{\mathrm{p}}\right)$ is in the range from 0.378 to $0.251 \mathrm{~J} / \mathrm{g}{ }^{\circ} \mathrm{C}$ and decreases for EPUUs with rapeseed-based polyols (Table 6). It can be concluded that the EPUUs with rapeseed-based polyols have a lower mobility of the flexible segments in the soft phase [42], especially EPUUs with RO polyol, with the lower molecular weight.

For all EPUUs, one endothermic peak on DSC curve, connected with dissociation of hydrogen bonds in the hard phase [8] and related with relaxation in the area of the hard domains, is observed (Fig. 9). The 100PEA has endothermic peak at $117.3{ }^{\circ} \mathrm{C}\left(T_{02}\right)$ with enthalpy $4.13 \mathrm{~J} / \mathrm{g}\left(\Delta H_{02}\right)$ (Table 6). 


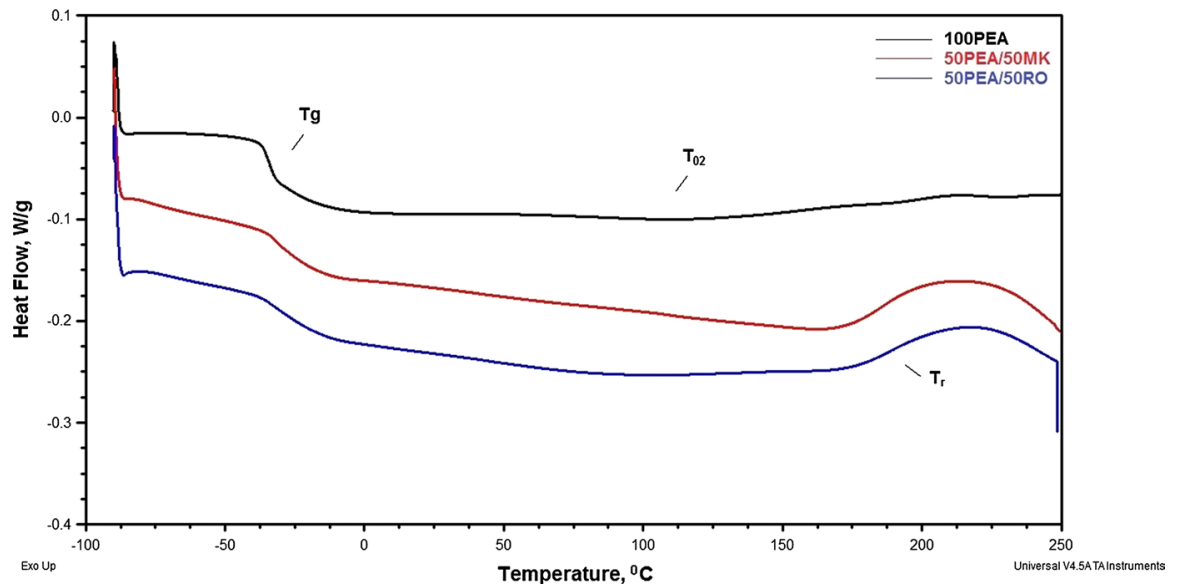

Fig. 9 DSC curves of tested EPUU and EPUUs with 50\% of MK and RO

Material $80 \mathrm{PEA} / 20 \mathrm{MK}$ has endothermic peak at $119.9{ }^{\circ} \mathrm{C}\left(T_{01}\right)$ with enthalpy $1.80 \mathrm{~J} / \mathrm{g}\left(\Delta H_{01}\right)$. For material 50PEA/50MK, neither endothermic peak was observed. Material 50PEA/50MK has higher glass transition temperature and temperature connected with the dissociation of hydrogen bonds than $80 \mathrm{PEA} / 20 \mathrm{MK}$, which shows that microdomains of this material have lower flexibility [25].

For EPUUs with $20 \%$ of RO polyol, endothermic peak at $92.5{ }^{\circ} \mathrm{C}\left(T_{01}\right)$ with enthalpy $4.51 \mathrm{~J} / \mathrm{g}\left(\Delta H_{02}\right)$ connected with changes in hard phase are observed. For $50 \%$ of RO polyol, endothermic peak is minimum at $96.4{ }^{\circ} \mathrm{C}\left(T_{01}\right)$ with enthalpy at $5.77 \mathrm{~J} / \mathrm{g}\left(\Delta H_{01}\right)$. For both groups of materials with MK and RO polyols, an exothermic peak starting at about $171.5^{\circ} \mathrm{C}\left(T_{\mathrm{r}}\right)$ is observed (Table 6). This peak is similarly to that observed in $\mathrm{MK}$ and $\mathrm{RO}$ polyols. According to the literature, transesterification process of polyols from rapeseed oils can be conducted at $180-240{ }^{\circ} \mathrm{C}$ [43].

\section{Mechanical analysis}

The viscoelastic properties of EPUUs were investigated during DMTA analysis. The curves of storage modulus $\left(E^{\prime}\right)$ and tangent of the phase shift angle $(\tan \delta)$ are shown in Fig. 10. The results interpreted from curves are summarized in Table 7.

The value of storage modulus in glassy state $\left(E^{\prime}{ }_{30}\right)$ is lower for EPUUs with rapeseed oil-based polyols. In the case of higher content of MK polyol, the increase in $E^{\prime}{ }_{-30}$ from 2.26 to $15.19 \mathrm{GPa}$, is observed. Above viscoelastic state $\left(E_{20}^{\prime}\right)$, the decrease in storage modulus for EPUUs with $20 \%$ of rapeseed oil-based content, is observed. For EPUUs with $50 \%$ of MK and RO polyols, an increase of $E^{\prime}{ }_{20}$ from 0.03 to $0.17 \mathrm{GPa}$ and from 0.06 to $0.22 \mathrm{GPa}$ is observed, respectively. In higher temperature $\left(E_{60}^{\prime}\right)$, the same characteristic for EPUUs is observed (Table 7). At some $E^{\prime}$ curves, the rubbery plateau is also observed (100PEA, 80PEA/20MK and 80PEA/20RO). For these samples, the data for cross-linking degree $\left(\nu_{\mathrm{c}}\right)$ were calculated (Table 7 ). The addition of $20 \%$ of MK and RO polyols causes an increase in $\nu_{\mathrm{c}}$ from 10.6 to $49.7 \mathrm{~mol} / \mathrm{kg}$ and $19.4 \mathrm{~mol} / \mathrm{kg}$, respectively. 


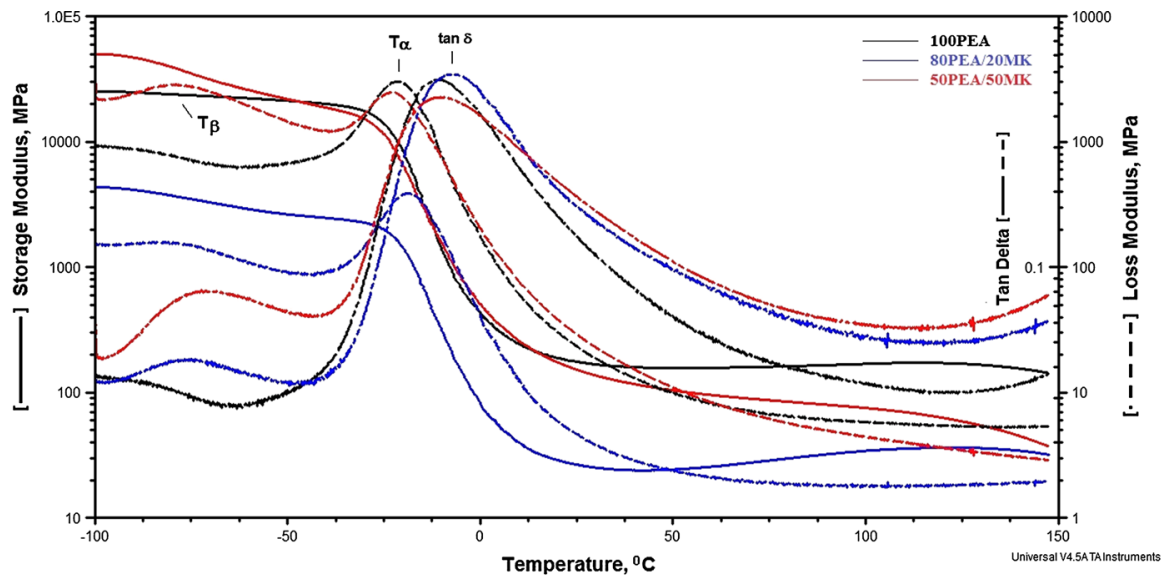

(a)

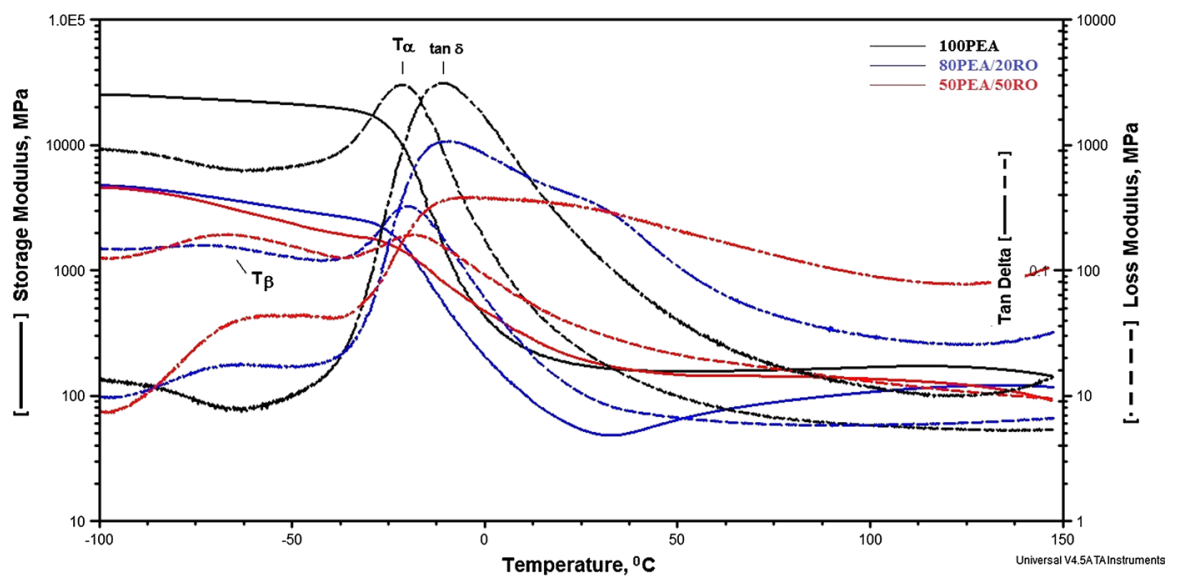

(b)

Fig. 10 DMTA curves ( $E^{\prime}$ modulus, $E^{\prime \prime}$ modulus and $\tan \delta$ ) for EPUUs with a MK and b RO polyols

In these materials, the strong hydrogen bonding between HSs and weaker ones between soft segments was created [44], what is shown by DPS (Table 3).

From loss modulus curves $\left(E^{\prime \prime}\right)$, the $\alpha$ relaxation temperature $\left(T_{\alpha}\right)$, related with the glass transition temperature $\left(T_{\mathrm{g}}\right)$ of soft segments, was determined (Table 7$)$. For EPUUs with MK polyol, the temperature $T_{\alpha}$ decreases with an increase in MK polyol content. In case of EPUUs with RO polyol, the increase of $T_{\alpha}$ is observed. For material 50PEA/50MK, the highest mobility of the segments of microdomains was received. The temperature $T_{\alpha}$ from DMTA can be compared with glass transition temperature $T_{\mathrm{g}}$ from DSC. In case of materials with RO polyol, the characteristic for these temperatures is the same. But for materials with MK polyol, the relation is opposite. 


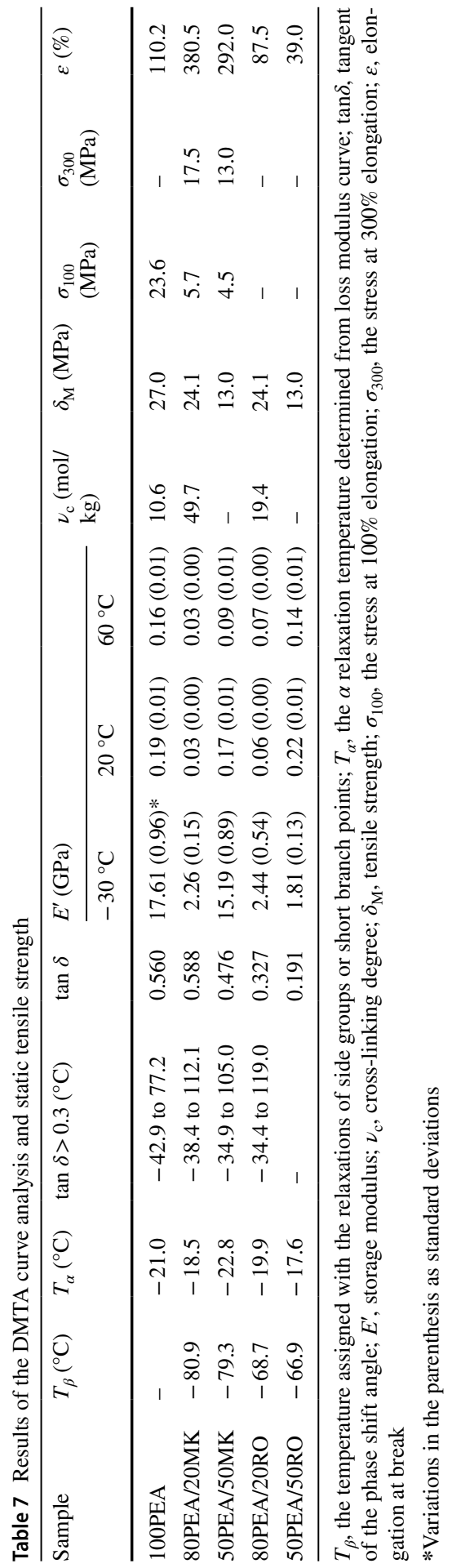


For material with MK and RO polyol, the temperature assigned with the relaxations of side groups or short branch points $\left(T_{\beta}\right)$ is observed (Table 7$)$. This temperature increased with an increase in rapeseed oil-based polyols content. Probably, this is an effect of limited mobility of microparticles [45].

The $\tan \delta$ curve corresponds to the ratio of $E^{\prime \prime}$ to the $E^{\prime}$. The ability to absorb energy by tested materials is considered by $\tan \delta>0.3$ [46]. The materials with high vibration adsorption and energy accumulation capacity characterized with tan $\delta>0.3$ in wide temperature range [47]. The EPUUs with MK and RO polyols have greater temperature range (Table 7). The maximum of the peak of $\tan \delta$ decreased with an increase in rapeseed oil-based polyols, and for material 50PEA/50RO the $\tan \delta<0.3$.

Based on the DMTA results, differences were found between the features of soft phase of the tested materials, which are also observed in the results based on DSC study (Table 6). For materials with RO polyol, the temperature $T_{\mathrm{g}}$, determined on the basis of the DSC thermogram, increases with an increase in RO polyol content in EPUUs. The $T_{\alpha}$ temperature, determined in DMTA, indicating relaxation capacity of soft phase after glass transition for EPUUs with RO polyol, also increases along with the increase in RO polyol content (Table 7). For EPUUs with MK polyol, the temperature $T_{\mathrm{g}}$, determined from DSC curves, also increases with an increase in MK polyol content. The $T_{\alpha}$ temperature, determined in DMTA, for EPUUs with MK polyol decreases for material with $50 \%$ of MK polyol to $-22.8^{\circ} \mathrm{C}$. This means that this material considerably differs in terms of relaxation capacity, which is the result of differences in the structure of MK polyol [21].

Static tensile strength was also tested to assess the mechanical properties of EPUUs. The results are summarized in Table 7. The tensile strength $\left(\delta_{\mathrm{M}}\right)$ decreased with an increase in MK and RO polyols content. For materials 100PEA, 80PEA/20MK and 50PEA/50MK, the stress at $100 \%$ elongation $\left(\sigma_{100}\right)$ is also observed. The $\sigma_{100}$ decreased with an increase in MK polyol content and is much lower than for the reference sample 100PEA. EPUUs with MK polyol stress at $300 \%$ elongation are also observed and decreased with an increase in MK polyol content. Elongation at break $(\varepsilon)$ for 100 PEA occurs at $110.2 \%$. For EPUUs with MK and RO polyols, the $\varepsilon$ occurred at $380.5 \%$ and $292.0 \%$, and $87.5 \%$ and $39.0 \%$, respectively. The elongation at break decreases with an increase in rapeseed oil-based polyols, which is confirmed by DPS (Table 3). The elongation at break is higher over $270 \%$ for $80 \mathrm{PEA} / 20 \mathrm{MK}$ and over $180 \%$ for $50 \mathrm{PEA} / 50 \mathrm{MK}$ than for 100PEA.

\section{Conclusions}

The paper presents the results of research on the impact of different structure and functionality of used rapeseed-based polyols on the thermal and mechanical properties of tested EPUUs. The use of rapeseed oil-based polyol in production of EPUUs caused changes of phase separation degree in these materials. As the content of MK and RO polyols increases, the number of hydrogen bonds connecting the rigid segments of these materials is reduced. The consequence of these changes in chemical 
structure in EPUUs, a change in the thermal characteristics of these materials, takes place.

The differences in structure of used rapeseed-based polyols in production of EPUUs are visible in mechanical properties of tested materials. Cross-linking density calculated from DMTA increases for materials with $20 \%$ of rapeseed oil-based polyols and is highest for material $80 \mathrm{PEA} / 20 \mathrm{MK}$. The elongation at break was higher for materials with MK polyols than for material with petrochemical polyol.

The use of diethylene glycol to opening oxirane rings in production of MK polyol caused higher mechanical properties in EPUUs, than for EPUUs with RO polyol produced with isopropanol.

Acknowledgements The authors would like to acknowledge the support of the Faculty of Materials Science and Engineering, Warsaw University of Technology within the Grant No. 504M/1090/1221/000.

Open Access This article is distributed under the terms of the Creative Commons Attribution 4.0 International License (http://creativecommons.org/licenses/by/4.0/), which permits unrestricted use, distribution, and reproduction in any medium, provided you give appropriate credit to the original author(s) and the source, provide a link to the Creative Commons license, and indicate if changes were made.

\section{References}

1. Kurańska M, Prociak A, Kirpluks M, Cabulis U (2015) Polyurethane-polyisocyanurate foams modified with hydroxyl derivatives of rapeseed oil. Ind Crops Prod 74:849-857

2. Datta J, Głowińska E (2014) Effect of hydroxylated soybean oil and bio-based propanediol on the structure and thermal properties of synthesized bio-polyurethanes. Ind Crop Prod 61:84-91

3. Bhoyate S, Ionescu M, Radojcic D, Kahol PK, Chen J, Mishra SR, Gupta RK (2017) Highly flameretardant bio-based polyurethanes using novel reactive polyols. J Appl Polym Sci 135(12):46027. https://doi.org/10.1002/app.46027

4. Kurańska M, Prociak A (2016) The influence of rapeseed oil-based polyols on the foaming process of rigid polyurethane foams. Ind Crops Prod 89:182-187

5. Kairyte A, Vejelis A (2015) Evaluation of forming mixture composition impact on properties of water blown rigid polyurethane (PUR) foam from rapeseed oil polyol. Ind Crops Prod 66:210-215

6. Gaidukova G, Ivdre A, Fridrihsone A, Verovkins A, Cabulis U, Gaidukovs S (2017) Polyurethane rigid foams obtained from polyols containing bio-based and recycled components and functional additives. Ind Crops Prod 102:133-143

7. Yang LT, Zhao CS, Dai CL, Fu LY, Lin SQ (2012) Thermal and mechanical properties of polyurethane rigid foam based on epoxidized soybean oil. J Polym Environ 20(1):230-236

8. Mizera K, Ryszkowska J (2016) Polyurethane elastomers from polyols based on soybean oil with a different molar ratio. Polym Degrad Stab 132:21-31

9. Mizera K, Ryszkowska J (2018) Thermal properties of polyurethane elastomers from soybean oilbased polyol with a different isocyanate index. J Elastom Plast 1:21. https://doi.org/10.1177/00952 44318772323

10. Hu YH, Gao Y, Wang DN, Hu CP, Zu S, Vanoverloop L, Randal D (2002) Rigid polyurethane foam prepared from a rapeseed oil based polyol. J Appl Polym Sci 84:591-597

11. Das B, Konwar U, Mandal M, Karak N (2013) Sunflower oil based biodegradable hyperbranched polyurethane as a thin film material. Ind Crops Prod 44:396-404

12. Yadav S, Zafar F, Hasnat A, Ahmad S (2009) Poly(urethane fatty amide) resin from linseed oil —a renewable recourse. Prog Org Coat 64:27-32

13. Thakur S, Karak N (2013) Castor oil-based hyperbranched polyurethanes as advanced surface coating materials. Prog Org Coat 76:157-164 
14. Kairyte A, Vaitkus S, Vejelis S, Girskas G, Balciunas G (2018) Rapeseed-based polyols and paper production waste sludge in polyurethane foam: physical properties and their prediction models. Ind Crops Prod 112:119-129

15. Javni I, Zhang W, Petrovics Z (2004) Soybean oil based polyisocyanurate rigid foams. J Polym Environ 12:123-129

16. Frifrihsone A, Stirna U, Lazdina B, Misane M, Vilsone D (2013) Characterization of polyurethane networks structure and properties based on rapeseed oil derived polyol. Eur Polym J 49:1204-1214

17. Tan S, Abraham T, Ference D, Macosko CW (2011) Rigid polyurethane foams from a soybean oilbased polyol. Polym 52(13):2840-2846

18. Auguścik M, Kurańska M, Prociak A, Karalus W, Lipert K, Ryszkowska J (2016) Production and characterization of poly(urea-urethane) elastomers synthetized from rapeseed oil-based polyols. Part I. Structure and properties. Polimery 61(7-8):490-498

19. Ryszkowska J, Auguścik M, Kurańska M, Oliwa R, Czech-Polak J, Prociak A (2017) Preparation and characterization of poly(urea-urethane) elastomers synthetized from rapeseed oil-based polyols. Part II. Thermal properties. Polimery 62(2):136-143

20. Yakushin V, Stirna U, Sevastyanova I, Vilsone D, Zeltins V, Kirpluks M (2013) Properties of polyurethanes based on tall oil fatty acids ester with different types of flame retardants. Key Eng Mater 559:115-120

21. Pietrzak K, Kirpluks M, Cabulis U, Ryszkowska J (2014) Effect of the addition of tall oil-based polyols on the thermal and mechanical properties of ureaurethane elastomers. Polym Degrad Stab 108:201-211

22. Mizera K, Kirpluks M, Cabulis U, Leszczyńska M, Półka M, Ryszkowska J (2018) Characterisation of ureaurethane elastomers containing tall oil based polyols. Ind Crops Prod 113:98-110

23. Marcovich NE, Kurańska M, Prociak A, Malewska E, Kulpa K (2017) Open cell semi-rigid polyurethane foams synthesized using palm oil-based bio-polyol. Ind Crops Prod 102:88-96

24. Marcovich NE, Kurańska M, Prociak A, Malewska E, Bujok S (2017) The effect of different palm oil-based bio-polyols on foaming process and selected properties of porous polyurethanes. Ind Crops Prod 66:1522-1529

25. Kirpluks M, Cabulis U, Kurańska M, Prociak A (2013) Three different approaches for polyol synthesis from rapeseed oil. Key Eng Mat 559:69-74

26. Zieleniewska M, Leszczyński MK, Kurańska M, Prociak A, Szczepkowski L, Krzyżowska M, Ryszkowska J (2015) Preparation and characterisation of rigid polyurethane foams using a rapeseed oilbased polyol. Ind Crops Prod 74:887-897

27. Mizera K, Chrząszcz M, Ryszkowska J (2018) Thermal and mechanical properties of ureaurethane elastomer composites with hollow glass spheres. Polym Compos 39(6):2019-2028

28. Ryszkowska J (2012) Supermolecular structure, morphology and physical properties of urea-urethane elastomers. Polimery 57(11-12):777-785

29. Krongauz VV (2010) Crosslink density dependence of polymer degradation kinetics: photo crosslinked acrylates. Thermochim Acta 503-504:70-84

30. Chen R (2012) Synthesis and characterization of tall oil fatty acid based thermoset resin suitable for natural fiber reinforced composite. University of Boras, School of Engineering, Boras

31. Ribeiro da Silva V, Mosiewicki MA, Yoshida MI, Coelho da Silva M, Stefani PM, Marcovich NE (2013) Polyurethane foams based on modified tung oil and reinforced with rice husk ash I: synthesis and physical chemical characterization. Polym Test 32:438-445

32. Narine SS, Kong X, Bouzidi L, Sporns P (2007) Physical properties of polyurethanes produced from polyols from seed oils: I. J Am Oil Chem 84:55-63

33. Pretsch T, Jakob I, Müller W (2009) Hydrolytic degradation and functional stability of a segmented shape memory poly(ester urethane). Polym Degrad Stab 94(1):61-73

34. Bryśkiewicz A, Zieleniewska M, Przyjemska K, Chojnacki P, Ryszkowska J (2016) Modification of flexible polyurethane foams by the addition of natural origin fillers. Polym Degrad Stab 132:32-40

35. Ryszkowska J (2011) The role of chemical structure and production process in morphology formation and polyurethanes materials properties. Publishing House of the Warsaw University of Technology, Warsaw

36. Trzebiatowska PJ, Deuter I, Datta J (2017) Cast polyurethanes obtained from reactive recovered polyol intermediates via crude glycerine decomposition process. React Funct Polym 119:20-25

37. Stirna U, Sevastyanova I, Misane M, Cabulis U, Beverte I (2006) Structure and properties of polyurethane foams obtained from rapeseed oil polyols. Proc Estonian Acad Sci Chem 55(2):101-109 
38. Ye L, Meng XY, Ji X, Li ZM, Tang JH (2009) Synthesis and characterization of expandable graphite-poly(methyl methacrylate) composite particles and their application to flame retardation of rigid polyurethane foams. Polym Degrad Stab 94(6):971-979

39. Yeganeh H, Mehdizadeh MR (2004) Synthesis and properties of isocyanate curable millable polyurethane elastomers based on castor oil as a renewable resource polyol. Eur Polym J 40:1233-1238

40. Ciecierska E, Jurczyk-Kowalska M, Bazarnik P, Kowalski M, Krauze S, Lewandowska M (2016) The influence of carbon fillers on the thermal properties of polyurethane foam. J Therm Anal Calorim 123:283-291

41. Wunderlich B (2012) Thermal analysis. Elsevier, New York

42. Xing WY, Hu Y, Song L, Chen XL, Zhang P, Ni JX (2009) Thermal degradation and combustion of a novel UV curable coating containing phosphorus. Polym Degrad Stab 94(7):1176-1182

43. Cervantes-Uc J-M, Moo Espinosa JI, Cauich-Rodrí-guez JV, Avila-Ortega A, Vazquez-Torres H, Marcos-Fernandez A, San Roman J (2009) TGA/FTIR studies of segmented aliphatic polyurethanes and their nanocomposites prepared with commercial montmorillonites. Polym Degrad Stab 94(10):1666-1677

44. Petrovic Z, Zavargo Z, Flynn JH, Macknight WJ (1994) Thermal degradation of segmented polyurethanes. J Appl Polym Sci 51:1087-1095

45. Sałasińska K, Borucka M, Celiński M, Gajek A, Zatorski W, Mizera K, Leszczyńska M, Ryszkowska J (2017) Thermal stability, fire behavior, and fumes emission of polyethylene nanocomposites with halogen-free fire retardants. Adv Polym Technol 37:2394-2410. https://doi.org/10.1002/ adv.21914

46. Mizera K, Auguścik M, Woronka D, Lipert K, Karalus W, Ryszkowska J (2016) Polyurethane composites with mixture of carbon fibers and glass frit. Polimery 5:307-315

47. Wang T, Chen S, Wang Q, Pei X (2010) Damping analysis of polyurethane/epoxy graft interpenetrating polymer network composites filled with short carbon fiber and micro hollow glass bead. Mater Des 31(8):810-3815

Publisher's Note Springer Nature remains neutral with regard to jurisdictional claims in published maps and institutional affiliations. 